\title{
Acceptance of the Application of Sustainable Concept in Malaysia's Waste Management Infrastructure - Landfill
}

\author{
Tey Jia Sin ${ }^{1, *}$, Goh Kai Chen ${ }^{1}$, and Peniel Ang Soon Ern ${ }^{2}$ \\ ${ }^{1}$ Faculty of Technology Management and Business, Universiti Tun Hussein Onn Malaysia, Batu \\ Pahat, Johor, Malaysia \\ ${ }^{2}$ Faculty of Engineering Technology, Universiti Tun Hussein Onn Malaysia, Batu Pahat, Johor, \\ Malaysia
}

\begin{abstract}
Sustainable concept has been a topic that is of broad and current interest in applying in many different areas of development. A sustainable concept encompasses three main criteria, namely environmental, social, and economic. This sustainable concept has usually been defined as the ability to develop something to meet the present needs yet it does not compromise the ability of future generation to meet their needs. Whereas waste management plays an important role in managing the municipal solid wastes produced. The landfill has been widely used in the disposal of solid wastes. However, the negative impacts caused by landfill have led to the need for application of sustainable concept. The acceptance of sustainable concept by stakeholders will determine the possibility of moving into sustainable waste management. This study aims at assessing the of acceptance by the stakeholders in the application of the sustainable concept into landfill. The research was conducted by reviewing of the past similar researches and through interview with ten waste management stakeholders. The results obtained show that there are some limitations in terms of understanding on the concept of sustainability and the willingness in accepting on this concept. Further action should taken in and moving towards sustainable waste management.
\end{abstract}

\section{Introduction}

The tremendous growth in Malaysian economy has led to the growth in the population along with the great influx of foreign workforce to cities. This phenomenon gives result an increase amount of wastes generated [1]. The increase of the production of municipal solid waste has brought to the need of having a proper waste management system. Besides, solid waste is already a significant problem for the Malaysian government [2].

Most of the municipal solid wastes produced in Malaysia are being disposed in landfill. This is due to the fact that some of the municipal solid wastes composition is not suitable to be burned and Malaysia is yet to have such technology to handle all different kinds of

* Corresponding author: jiasin.star@gmail.com 
wastes. If the present rate of solid waste production goes on without effective supervision and disposal methods, there will be a substantial negative impact on the quality of our environment [2]. This implies that a waste management system that is sustainable is required. Through the application of sustainable concept into the waste management system, it could help to manage the solid wastes in a way that could minimise the impact to the environment, social, and economy.

\section{Literature review}

With all the negative impacts that landfill may cause, it is essential to tackle and provide a better solution for it through the application of sustainable concept. Besides, environmental problems caused by waste management have increased the pressure on waste managers, planners, and regulators. These push them to implement sustainable waste management in their projects [3] as well as selecting the sustainable option in managing waste. In this section, effort is made to search into the related literature in order to review the principle of sustainable development, acceptance as well as waste management infrastructure in Malaysia in relation to landfill

\subsection{Principle of sustainable development}

There are several ways to define the concept of sustainability. One of them is sustainability is the ability in sustaining the earth's resources while it is being exploited. The areas involved in sustainability are environmental responsibility, social awareness, and economic profitability [4]. In this context, sustainable concept is the idea of maintaining current resources for our future generation although the resources are being used for different purposes. This concept has slowly gained recognition by different agency and promotion in order to protect current resources from being exhaustively exploited. Thus, it is good to apply it into the management of municipal solid wastes.

Sustainable solid waste management aims to offer a chance to prevent waste through designs based on the full life cycle of the product, similar to natural cycles, which function without producing waste [5]. One of the researchers also supported that there is a need to work towards a sustainable waste management system, which requires environmental, institutional, financial, economics, and social sustainability [6].

There are many drivers affecting sustainability and the impact varies from one country to another, depending on political, socio-economic and environmental factors. The scenario is more complicated in Asia due to rapid industrialization and urbanization and changing waste composition and generation rates. Waste management technologies are generally conservative in Asia and the need for integrated waste management is imperative [7].

Sustainable landfill sites are becoming difficult to find as urban areas expand. Also, individuals are not willing to accept the implementation of a new landfill site near them because of concerns about smell, litter, pollution, pets, and the reduction in the value of their homes. There are large costs involved in providing conveniently located and environmentally responsible landfill facilities [5].

As a whole, the implementation of sustainable concept is about to bring more advantages to the waste management industry than the disadvantages. It should be accepted widely by the waste management stakeholders and applied in the daily decision of disposing waste through landfill. 


\subsection{Acceptance}

Several researches have defined acceptance in different manners. Attitude, knowledge and support are the main factors to impinge on the acceptance of sustainable agriculture among farmers, but studies on the same scenario are lacking for Malaysia [8]. Furthermore, from a knowledge perspective, we can distinguish the transition in knowledge approaches for every type of agriculture, from conventional model to a sustainable one. Through this definition, though, Malaysia still lacking of the similar study yet the attitude, knowledge and support possess by the stakeholder can be a measure of the acceptance towards sustainable.

On the other hand, the acceptance is also being defined as the reflection of the behaviour that enables or promotes the use of a technology, rather than inhibits or demotes the use of it. Support can be expressed in proclaiming the technology (for example because of its environmental benefits, or purchasing and using the technology [9].

The lack of definition of acceptance as well as a model or framework in which to understand acceptance, and the drives behind it present a significant barrier both for understanding and working with acceptance. Since acceptance if developed by the individual it can only be based on the individual's perception of the system [10]. As a whole, the degree of acceptance towards sustainable concept can be identified through the individual attitude, knowledge possession and support that apply in the real practical work. An individual who is willing to accept will be shown through his action and attitude.

Hence, in this paper, the degree of acceptance towards the sustainable concept into waste management is based on the individual perception and the knowledge possess by the individual. It will be discussed in the following sections.

\subsection{Waste management infrastructure in Malaysia - landfill}

The major challenge in the urban areas, especially in the fast growing cities and towns is the management of solid waste. The reason behind it is the ever increasing population which lead to the increment of waste generation [11]. This is supported by Noor et al. [12] who also highlighted that the increasing population and rapid urbanization in Malaysia directly influence a municipal solid waste generation. This showed the needs to improve waste management system in order to contain the increasing amount of solid wastes.

Samsudin et al. [13] stated that there are about 230 municipal waste disposal sites in operation in Malaysia. However, most of the municipal waste disposal sites are open dumping sites, whereby the disposal of solid wastes are not operating according to the guideline and the sites are not well managed. Hence, the increasing quantities of wastes have made the efficient management of solid waste in Malaysia more important.

One of the main waste management technique adopted by Malaysia in handling the disposal of the solid waste is through landfill. However, although landfill appears to be capable of managing most of the solid wastes produced, but it undeniably has caused many negative impacts as well. Among the negative impacts are production of pollutants which include noise, odours, unsightliness, and air pollution through the heavy vehicle movement. It will contaminate the land and cause the land unsuitable for other usage purposes in the near future $[14,15]$. In short, it brings negative social impacts towards the residents who stay near to the landfill sites. Both leachates and biogas that are the pollutant generated from the landfill. Biogas such as methane is generated from landfill and is released to the atmosphere is capable of causing global warming. The volume of biogas is estimated to be 23 times greater than that of the same volume of carbon dioxide gas [16]. All these negative impacts could be reduced by the implementation of sustainable concept into the construction of landfill, its operation and selecting the landfill sites. 
Some authorities in Malaysia could not select a land for disposal site as the land is getting scarce and high cost is required in land acquisition [17]. The sites far from the source of waste generation increase transfer costs and require additional investments for infrastructure as well. Moreover, the solid waste is also often thrown directly into the waterways and rivers, or dumped on the roadside. Especially in the countryside, the amount of waste dumped openly is not known, without any environmental perspective plans. The reasons for these problems are lack of finance, land acquisition problems, and insufficient waste- collection and transfer system [5]. Through the stakeholders who possess the sustainable concept, a good landfill site that consists of sustainable criteria can be obtained.

\section{Research methodology}

This paper employed literature review and qualitative study, which is semi- structured interview to gather a more in- depth information from waste management industry. A total of ten waste management stakeholders who involved in the evaluation of a landfill site from the government sectors are interviewed.

The aim of this research is to identify the acceptance towards the implementation of the sustainable concept into waste management system. The concept of sustainability is desired to be implemented in the consideration of a suitable land to turn it into a landfill site. Thus, the perspective of each respondent which represents each government sector is to be determined in this research as well. The semi structured interview can provide the information for the development of a sustainable waste management.

\subsection{Profile of respondents}

The list of respondents is shown in Table 1. Among the departments are National Solid Waste Management Department, local authorities, State Economic Planning Unit, Public Work Department, Department of Environment, Town and Country Planning Department, Department of Irrigation and Drainage, Land Department, Solid Waste Management and Public Cleansing Corporation and a private company who works on managing solid waste.

Table 1. Respondents' Profile

\begin{tabular}{|c|c|c|}
\hline No. & Position & Department \\
\hline R1 & Assistant Director & $\begin{array}{l}\text { Department of National Solid } \\
\text { Waste and Management }\end{array}$ \\
\hline R2 & Assistant Director & $\begin{array}{l}\text { Solid Waste and Public } \\
\text { Cleansing Management }\end{array}$ \\
\hline R3 & Assistant Director & Department of Environment \\
\hline $\mathrm{R} 4$ & Assistant Director & $\begin{array}{c}\text { Town and Country Planning } \\
\text { Department }\end{array}$ \\
\hline R5 & Assistant Director & State Economic Planning Unit \\
\hline R6 & $\begin{array}{l}\text { Head of Assistant } \\
\text { Director }\end{array}$ & $\begin{array}{c}\text { Department of Irrigation and } \\
\text { Drainage }\end{array}$ \\
\hline R7 & Assistant Engineer & Public Work Department \\
\hline R8 & Deputy & Local Authorities \\
\hline R9 & $\begin{array}{c}\text { Assistant } \\
\text { Administrative }\end{array}$ & Land and Survey Department \\
\hline R10 & Project Engineer & Private Company \\
\hline
\end{tabular}

Most of the respondents are professionals which are in high positions of making decision. Most of them are from different background which inferably contributed a vast 
variety of reliable information. The interview questions have been sent out to all the respondents prior to the interview session conducted.

\section{Results and discussion}

This research is aims in finding out the acceptance of sustainability concept in waste management industry by the waste management stakeholders. As stated in related literature as earlier reviewed, sustainability is the ability to sustain the earth's resources while it is being exploited. The areas involved in sustainability are environmental responsibility, social awareness, and economic profitability [4]. It can be clearly seen that there are two parties from each department that do not possess the whole understanding of sustainable concept.

It has been found out that all the respondents agreed to the importance of sustainability in the landfill site selection. It is also encouraging to obtain the information that all of the respondents seeing the importance to have the concept of sustainability. However, not all the government departments have applied it into the process of evaluation of a site to be used as landfill (see Fig. 1).

Based on Fig. 1, it can be observed that there are $90 \%$ of the respondents from each department that supported and implemented the concept of sustainability into the landfill site selection. However, through the data collected from the respondents, most of them are not applying the whole aspects of sustainability aspects into the landfill site selection. Some of the views of the respondents are presented as follows:

Yes, in this department, we did emphasize on sustainable concept. For example they set up buffer zones whereby they need to plan many trees. (R3)

Yes, it is very important. However, for Department of Environment, the environment and social aspects have always been emphasized in the evaluation of landfill site selection. (R5)

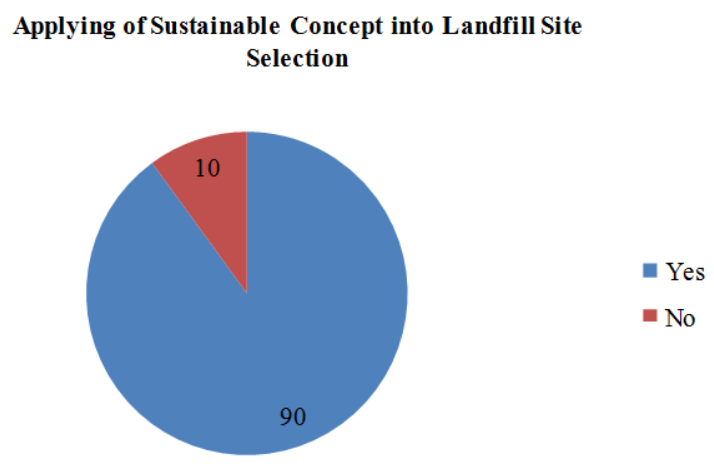

Fig. 1. The Application of Sustainable Concept into Landfill Site Selection.

It can be observed that most of the respondents claimed to apply the concept of sustainability in the process of site selection. Among the respondents are R1, R2, R3, R4, R5, and R6, with each representing different departments. Conversely, most of them are only able to take into consideration on environmental aspects and some social aspects. This also implies that there is a strong urge to further emphasize the sustainable concept and to help all the related parties to get the full understanding of sustainability aspects. 
From Fig. 1, that other $10 \%$ is on the Public Work Department. As the respondents stated:

I do agree that the concept of sustainability is important, however, it is not implemented in this department because the Public Work Department is focusing on the road and access only. (R7)

The Public Work Department's focus on the road and access has pushes them found that it is not necessary to integrate sustainable concepts into landfill site selection. It is important to help them to be aware of working as a whole unit in the landfill site selection and the importance of how each department chooses to contribute the best idea in the landfill site selection.

On the other hand, R1 and R9 expressed that they do not understand the sustainable concept before this interview session, while R4 mistakenly thought that the sustainable concept is focused only on the environmental criteria and R2 regarded that sustainability is all about the separation of the solid waste at its source. However, all these respondents were willing to accept and consider applying this concept into the management of solid wastes after listening to what sustainability concept is all about.

However, Respondents 6, 8 and 10 showed the understanding and willingness to accept the application of the sustainable concept into landfill. These small part of respondents showed that there are still some waste management stakeholders whom possessed the understanding and good response to the sustainability concept. Respondent 8 expressed the sustainable concept as:

\section{Sustainable concept is a way to plan for future usage. Also, it is environmental friendly} (R8)

From the data obtained, it can be concluded that the concept of sustainability is yet to be widely comprehended by all the waste management stakeholders. Mohamed [18] also supported that there is a lack of knowledge in the sustainable concept in the local governments and that it would in turns cause several issues such as improper public sanitation among others. Although the importance of sustainability has been agreed and acknowledged by the respondents. Most of the respondents still need to be educated in order for them to realise the benefits of adopting sustainable concept into their real life project. The conclusion can be drawn that the basic knowledge of sustainability has not been fully captured and applied into all the relevant parties and their job scope. Hence, it strengthens the needs to promote sustainable concept into waste management system, landfill.

\section{Conclusion}

Sustainable concept is getting more attention and being used in different industries. Due to the increasing number of municipal solid wastes in a country, it led to the need in improving the waste management industry. This can be done by implementing the concept of sustainability in the operation of waste management system. Therefore, it requires the acceptance by the waste management stakeholders in order to be implemented in Malaysia waste management industry. However, through the research, it is found out that the acceptance of the sustainable concept in Malaysia at this stage is still considerably low. Moreover, the results have reflected that their understanding towards the concept of sustainability is also low. From the study, it reinforces the need of imparting the concept of 
sustainability to the waste management stakeholders as to improve the whole waste management industry.

The authors express grateful acknowledgement to the industry stakeholders for their valuable contributions towards the success of this research. This research was partly sponsored by the Centre for Graduates Studies UTHM.

\section{References}

[1] S. Kathirvale, M. N. Muhd Yunus, K. Sopian, and A. H. Samsuddin, Energy potential from municipal solid waste in Malaysia, Renewable energy, 29, 559-567, (2004)

[2] S. A. Haron, L. Paim, and N. Yahaya, Towards sustainable consumption: an examination of environmental knowledge among Malaysians, International Journal of Consumer Studies, 29, 426-436, (2005)

[3] R. Minciardi, M. Paolucci, M. Robba, and R. Sacile, A Multi-objective Approach for solid waste management, in Proc. iEMSs, 205-210, (2002)

[4] M. Pitt, M. Tucker, M. Riley, and J. Longden, Towards sustainable construction: promotion and best practices, Construction Innovation: Information, Process, Management, 9, 201-224, (2009)

[5] U. N. Ngoc and H. Schnitzer, Sustainable solutions for solid waste management in Southeast Asian countries, Waste Management, 29, 1982-1995, (2009)

[6] S. Rathi, Alternative approaches for better municipal solid waste management in Mumbai, India, Waste Management, 26, 1192-1200, (2006)

[7] P. Agamuthu, S. Fauziah, K. Khidzir, and A. N. Aiza, Sustainable waste managementAsian perspectives, in Proceedings of the international conference on sustainable solid waste management, 15, (2007)

[8] A. Azman, J. L. D'Silva, B. A. Samah, N. Man, and H. A. M. Shaffril, Relationship between attitude, knowledge, and support towards the acceptance of sustainable agriculture among contract farmers in Malaysia, Asian Social Science, 9, 99, (2013)

[9] N. M. Huijts, E. Molin, and L. Steg, Psychological factors influencing sustainable energy technology acceptance: A review-based comprehensive framework, Renewable and Sustainable Energy Reviews, 16, 525-531, (2012)

[10]E. Adell, The concept of acceptance, in ICTCT-workshop, (2008).

[11]A. Johari, S. I. Ahmed, H. Hashim, H. Alkali, and M. Ramli, Economic and environmental benefits of landfill gas from municipal solid waste in Malaysia, Renewable and Sustainable Energy Reviews, 16, 2907-2912, (2012)

[12]Z. Z. Noor, R. O. Yusuf, A. H. Abba, M. A. Abu Hassan, and M. F. Mohd Din, An overview for energy recovery from municipal solid wastes in Malaysia scenario, Renewable and Sustainable Energy Reviews, 20, 378-384, (2013)

[13]A. R. Samsudin, B.-e. E. A. Rahim, W. Z. W. Yaacob, and U. Hamzah, Mapping of contamination plumes at municipal solid waste disposal sites using geoelectric imaging technique: Case studies in Malaysia, J. of Spatial Hydrology, 6, (2006)

[14]N. P. Cheremisinoff, Handbook of Solid Waste Management and Waste Minimization Technologies, First ed. United States of America: Butterworth-Heinemann, Elsevier Science, (2003)

[15]S. El Haggar, Sustainable Industrial Design and Waste Management: Cradle-ToCradle for Sustainable Development: Academic Press, (2010) 
[16] S. Renou, J. G. Givaudan, S. Poulain, F. Dirassouyan, and P. Moulin, Landfill leachate treatment: Review and opportunity, J. of hazardous materials, 150, 468-493, (2008)

[17]Z. Sakawi, Municipal solid waste management in Malaysia: Solution for sustainable waste management, J. of Applied Sciences in Environmental Sanitation, 6, 29-38, (2011)

[18]S. Mohamed, Preliminary concept of knowledge transfer practices towards sustainable development for local governments, In: MUCET 2015, 11-13 October 2015, Johor (2015) 